\title{
Household Demand Analysis for Pakistan: Recent Evidence
}

\author{
Falak Sher ${ }^{1}$ and Eatzaz Ahmad ${ }^{2}$
}

\begin{abstract}
The objective of this study is to analyze household demand system for Pakistan by estimating various elasticities of demand. This study combines nine different rounds of Household Integrated Economic Survey data to estimate Almost Ideal Demand System (AIDS). Household level data are supplemented with rich price information available for all the twelve months of the nine years. This approach yields efficient estimates of income and price elasticities, which are non-linear combinations of the parameters of AIDS. Standard errors for all the elasticity estimates are computed on the basis of Monte-Carlo simulations. The results show that household demand responses to income changes are similar between rural and urban households, while the response to price changes differ considerably. On average, rural households are found to be more responsive to price changes than the urban households. The study recommends that on equity grounds transport and communication and miscellaneous non-food goods and housing can be taxed more heavily as compared to other goods.
\end{abstract}

Keywords: Household, Pooled Data, Demand System, LA/AIDS, Elasticities, Pakistan

JEL Classification: D1, D12, R2

\section{Introduction}

Estimation of household demand has attracted a lot of attention both in theoretical and empirical literature, especially after the introduction of Almost Ideal Demand System (AIDS) of Deaton and Muellbauer (1980). Household consumption is the largest and important component of Gross Domestic Product. The household consumption patterns differ across households and across time because of the differences in income, prices and all such attributes that determine households' preferences. Various studies have emphasized, on the basis of empirical analysis, that own price of good or service, prices of other goods and services and income of the households are the most dominant factors of demand; for example, Massell (1969), Hay

\footnotetext{
${ }^{1}$ Lecturer, Department of Economics, University of Sargodha, Sargodha, Pakistan.

${ }^{2}$ Professor, Department of Economics, Quaid-i-Azam University, Islamabad, Pakistan.

Corresponding author’s Email: falak.sher@uos.edu.pk
} 
and Sinha (1972), Ray (1982), Yen and Jensen (1996), Burki (1997), Ozer (2003), Ahmad and Arshad (2007), Ekholm et al. (2010) and Aziz and Malik (2010).

The nature of household demand and the knowledge of its determinants are of crucial importance for accurate forecasting of the current and future needs of various goods and services. In this regard, the knowledge of the income and prices elasticities of demand would help the regulators to make future forecasts of demand and propose fiscal policies for regulation of the markets.

The literature on household demand for Pakistan is limited in its scope because of limited data availability. The available panel data are limited and outdated. Secondly, time series data does not provide sufficient information on consistent basis. As a result, most of the literature is based on cross-section data, which focuses on household level variables such as income and demography of households with no or very limited analysis of full demand.

Despite limitation of data, the literature has improved over time in terms of models specified, variables selection, estimation procedures and the use of data. Most of the earlier studies have relied on cross-section survey data and focused on the estimation of income elasticities only and the influence of household characteristics. The literature in 1980s and 1990s was mostly confined to Linear Expenditure System with no direct information on prices used (Ali, 1981, 1985; Ahmad and Ludlow, 1987; Ahmad et al., 1988; Ahmad and Malik, 1989; Malik et al., 1987, 1988; Burney and Akhtar 1990; and Burney and Khan, 1991). In some of the studies, estimates of own and cross price elasticities were derived by imposing the arbitrary condition on linear Engle equations, that, the utility function underlying the estimated linear Engle equations is of Stone-Geary type. Burki's (1997) study was perhaps the first one to estimate complete demand system using actual information on prices by relying on time-series data. Later a few studies that focused on energy demand (Khan and Ahmad, 2009; Jamil and Ahmad, 2010, 2011) employed time-series data to estimate demand functions for selected energy. More recently Ahmad et al. (2013) and Ahmad et al. (2020) have estimated complete demand systems on the basis of pooled cross-section and time-series data.

This shows how the literature on consumer demand in Pakistan is limited. Only a few studies have attempted to estimate the complete demand 
system using genuine price variation over time. However, these studies employed grouped data in which households in a survey were categorized into 12 income groups. This grouping caused substantial loss of information on cross sectional data variation.

Most of the past studies in Pakistan have used either pure time series or pure cross section data, which leads to loss of important information. On the other hand, in cross-section data, no useful data is available for price variation. The data on household characteristics is also missing in cross section data. In Pakistan panel data on household consumption are very limited and outdated. The other option to pool a number of cross-sectional data sets and to make use of the information contained both in crosssectional and time dimensions has not been fully explored. The main motivation to undertake this study is to fill this gap in the existing literature on Pakistan. Pooling data also enables to have a reasonably large sample to yield sufficient degrees of freedom.

With the data pooled across several years, it may be possible that consumers' preferences change over time due to the factors other than prices, income, and household characteristics. One such factor is the consumers' perceptions about general economic conditions prevailing in the economy that can force changes in their consumption plans. Therefore, it is important to include the key macroeconomic variables as control variables in the empirical analysis.

Apart from making use of year-to-year price variation in pooled data, it is also possible to utilize month-to-month price variation because the month of data collection can be extracted from micro data. This is possible because each survey is spread across the whole year in order to collect data on consumption of all the goods that are consumed in different seasons.

In order to let the data pick underlying relationship with minimal extraneous restrictions, the study employs AIDS. Among flexible demand models, AIDS is considered to be superior to other forms because it is consistent with theory, and it is flexible and simple to estimate. It does not require additive preferences and it can be aggregated perfectly over consumers. Restrictions of homogeneity and symmetry can be tested through linear restrictions on the fixed parameters (Deaton and Muellbauer, 1980). 
Since all the elasticity estimates are non-linear combinations of the parameters of AIDS, no direct information could be obtained on standard errors. In this context, another contribution of the study is that it provides distribution-free standard errors for elasticity estimates on the basis of Bootstrap simulations.

AIDS is a flexible demand system containing quite a few parameters that make its estimation difficult, especially with large data sets and limited computing capacity of software. It is, therefore, desirable to classify all the goods and services into a small number of manageable groups for empirical analysis, each containing more-or-less homogeneous goods and services. The grouping is also needed in the light of available data on prices. Thus, the study classifies consumer goods into eight broad categories, which are: Clothing; Housing; Grains; Milk, Meat and Oil; Other Foods; Fuel; Transport and Communication; and all other non-food goods (Miscellaneous).

The objectives of the present study are:

- To analyze household consumption decision for Pakistan by estimating own price, cross price and income elasticities of demand for different types of consumption goods for rural and urban areas of Pakistan.

- To demonstrate the advantage of pooling various sets of survey data collected in different years for efficient estimation of the demand system.

To control for macroeconomic environment over the sampled period, a number of macroeconomic variables that are expected to affect household consumption decisions are included in the analysis. The variables are anticipated and unanticipated yearly inflation rate; anticipated and unanticipated output level and growth rate of output. It is important to distinguish between anticipated and unanticipated economic conditions. The anticipated conditions are presumed to be known or at least expected beforehand and, hence, can be incorporated into the decision-making processes. Unanticipated conditions, on the other hand, surface as surprises and the consumers would respond to such shocks as stopgap arrangements.

The rest of the paper is organized as follows: Methodology and data are presented in Section 2 and 3 respectively. Section 4 deals with estimation and results. Section 5 provides concluding remarks. 


\section{Methodology}

The study uses Almost Ideal Demand System (AIDS) of Deaton and Meulbauer (1980), which is considered as a major breakthrough in demand system. The system is based on an expenditure function of the form given below, where $M, U, P$ denote total expenditure, utility and the price vector, respectively.

$$
\begin{aligned}
& \log \lfloor M(P, U)]=(1-U) \log [a(P)]+U \log [b(P)] \\
& \text { where } \\
& \log [a(P)]=\alpha_{0}+\sum_{k} \alpha_{k} \log \left(P_{k}\right)+\frac{1}{2} \sum_{k} \sum_{j} \gamma_{k j} \log \left(P_{k}\right) \log \left(P_{j}\right) \\
& \log \left[b(P)=\log [a(P)]+\beta_{0} \prod_{k}\left(P_{k}\right)^{\beta_{k}}\right.
\end{aligned}
$$

Substituting Equation (2) and (3) into Equation (1), yields:

$\log \lfloor M(P, U)\rfloor=\alpha_{0}+\sum_{k} \alpha_{k} \log \left(P_{k}\right)+\frac{1}{2} \sum_{k} \sum_{j} \gamma_{k j} \log \left(P_{k}\right) \log \left(P_{j}\right)+$ $U \beta_{0} \prod_{k}\left(P_{k}\right)^{\beta_{k}}$

The uncompensated demand function for any good $i$ is obtained in two steps. By taking derivative of the above expenditure function with respect to $\log \left(P_{i}\right)$ and applying Shepherd's lemma in the first step, the compensated demand function is obtained in the form of expenditure share equation of good ' $i$ '. The second step is to substitute in the resulting equation the indirect utility function, which can be obtained by inverting the above expenditure function. The result would be the following uncompensated demand system of good $i$ expressed in expenditure share form where $P^{*}$ is the price index:

$S_{i}=\alpha_{i}+\sum_{j} \gamma_{i j} \log \left(P_{j}\right)+\beta_{i} \log \left(\frac{M}{P^{*}}\right)$

$\log \left(P^{*}\right)=\alpha_{0}+\sum_{k} \alpha_{k} \log \left(P_{k}\right)+\frac{1}{2} \sum_{k} \sum_{j} \gamma_{k j} \log \left(P_{k}\right) \log \left(P_{j}\right)$

Based on theoretical properties of demand system ('homogeneity' and 'adding-up') the following restrictions are imposed on parameters of Equation (5) and (6):

$\gamma_{i j}=\gamma_{j i}, \quad \sum_{i} \alpha_{i}=1, \quad \sum_{i} \beta_{i}=0, \quad \sum_{i} \gamma_{i j}=0$

The study also uses data on five macroeconomic variables that may affect household demand for consumer goods. These are anticipated inflation rate, unanticipated inflation rate, anticipated and unanticipated components of GDP and the year-to-year growth rate of GDP. Anticipated 
and unanticipated components of inflation rate and GDP are derived from ARMA models fitted to log first differences of CPI and real GDP. ${ }^{3}$ In addition, month dummies are added to the model to allow for seasonality in demand patterns of the consumers. ${ }^{4}$

AIDS satisfies the standard theoretical properties of demand system. However, estimation of the system may run into difficulties because of nonlinearity in parameters. Deaton and Muellbauer (1980) have proposed to approximate the price index $P^{*}$ to a known price index, given below which, unlike the price index given in Equation (2), has no parameters to make the system non-linear.

$$
\log \left(P^{*}\right)=\alpha_{0}+\sum_{k} s_{k} \log \left(P_{k}\right)
$$

In a series of articles Green Alston (1990, 1991, 1993) have pointed out shortcoming in the income and price elasticity formulas that overlook the fact that expenditure shares also appear on right-hand side of the share equations through the above price index. The correct formulas for the price and income elasticities derived by them are given by Equation (9) and (10) below:

$$
\begin{aligned}
& E=[B C+1]^{-1}[A+I]-I \\
& N=(I+B C)^{-1} B+i
\end{aligned}
$$

where

$E$ is the $\mathrm{n} \times \mathrm{n}$ matrix of (own and cross) price elasticities $\eta_{\mathrm{ij}}$

$A$ is the $n \times n$ matrix of elements $a_{i j}=-\delta_{i j}+\left(\frac{\gamma_{i j}}{s_{i}}\right)-\beta_{i}\left(\frac{s_{j}}{s_{i}}\right)$

$B$ is the $n \times 1$ vector of elements $b_{i}=\left(\beta_{i} / s_{i}\right)$ in $\mathrm{n} \times 1$ vector $\mathrm{B}$ $C$ is the $1 \times n$ vector of elements $c_{j}=s_{j} \ln P_{j}$ in $1 \times \mathrm{n}$ vector $\mathrm{C}$

$N$ is the $\mathrm{n} \times 1$ vector of income elasticities $\eta_{\mathrm{iM}}$ $i$ is the $n \times 1$ matrix of ones

\footnotetext{
${ }^{3}$ See Enders (2015) on how ARMA models can be employed to divide a time series into anticipated and unanticipated components using the within-sample forecasts.

${ }^{4}$ Although the survey data on household expenditures are not given continuously for every year and every month of the given years, yet the anticipated and unanticipated components of macroeconomic variables are estimated using the continuous time series to ensure their proper estimation. Once all such series are constructed, the data for the months where household data are missing are dropped.
} 


\section{Data}

Micro data on household consumption expenditures are taken from Household Integrated Economic Survey conducted by Pakistan Bureau of Statistics for the years: 2001-02, 2004-05, 2005-06, 2007-08, 2008-09, 2010-11, 2011-12, 2013-14 and 2015-16. The data reported for different frequency are brought to common monthly frequency and various goods and services are classified into eight categories: 1) Grains (rice, wheat, lentils, peas and flours); 2) Milk, Meat and Oil (sources of protein, fats and calcium); 3) Other Foods (including vegetables, fruits, herbs, spices, sauces, bakery products, confectioneries, drinks); 4) Housing; 5) Clothing (all types of wears); 6) Fuel; 7) Transport and Communication; and 8) Miscellaneous Other Non-Food. The last category includes those goods and services that are not included in any other category.

Following the convention in empirical literature, especially for Pakistan household income is measured by total expenditures despite the availability of data on income. The reason is that it is suspected that households do not accurately report their incomes intentionally or unintentionally and there are conceptual issues with how income data are reported. ${ }^{5}$ Total expenditure is expressed in per adult equivalent terms using OECD adult equivalence scales, where value of 1 is assigned to the first household adult member; 0.7 to each additional adult member and of 0.5 to each child ${ }^{6}$.

The commodity group specific consumer price indices (CPIs) are either directly obtained from data sources of Federal Bureau of Statistics (e.g. Statistical Bulletin) or constructed on the basis of data available in the same sources. For some commodity groups price indies are calculated using the information on prices of the goods included in the groups. These price indices are based on Laspeyres price index using the expenditure weights for the base year taken from the household survey data. The study also uses dummy variables to capture the monthly effect on household demand for consumer goods using the month of March, being a 'normal' month as base month.

\footnotetext{
${ }^{5}$ See, for, example, Ahmad et al. (2013), Ahmad et al. (2020), Arshad and Ahmad (2006), Burney and Khan (1991), Malik et al. (1987) and Malik et al. (1988) and Shamim and Ahmad (2007).

${ }^{6}$ We do not need to express expenditure on any individual expenditure category in per adult equivalent terms because in the econometric analysis expenditures on all categories are used in expenditure share forms which are independent of such scaling.
} 


\section{Estimation and Results}

To cater for the possible contemporaneous correlation between errors of various share equations, the model is estimated as Seemingly Unrelated Regression (SUR) model using iterative Generalized Least Squares (GLS) method. To avoid singularity due to 'adding up' property of the demand system, the share equation for miscellaneous commodity group is dropped. The parameter estimates of this equation are later derived using the restrictions in Equation (7) and (9). The same set of restrictions is used to infer restrictions on variance-covariance matrix of the parameter estimators. These restrictions are then used to derive standard errors of parameter estimators of the dropped equation. The system is estimated separately for the urban and rural regions of Pakistan.

Parameter estimates of the model for urban and rural areas of Pakistan are presented in Tables A1 and A2 of Appendix. In each case 80 parameters of the main AIDS model and 40 parameters of macroeconomic conditioning variables are estimated. The results show that the percentage of statistically significant parameters of the main AIDS model is quite high, $81 \%$ (65 out of 80 ) in urban sample and $86 \%$ (69 out of 80 ) in the rural sample. The signs of $\beta$ s indicate whether income elasticities are greater than or less than one. Similarly, the signs and magnitudes of $\gamma \mathrm{s}$ can be related to own and cross price elasticities. Apart from this information, these parameter estimates do not provide any easy interpretation. Thus, this study presents all the income and price elasticity estimates as focus of analysis, there is no further need to discuss these parameter estimates.

Coming to economic variables, these are the control variables, included in the model to control for changing macroeconomic environment across survey years for which data are pooled. This is done as a better alternative to allowing period fixed effects when possibly heterogeneous data are pooled together. The results show that these variables have statistically significant correlation with households' decision making. The tables show that $88 \%$ (35 out of 40 ) of the parameters associated with these variables are statistically significant in urban sample and 93\% (37 out of 40) are statistically significant in the rural sample.

Turning now to the focus of analysis, that is the income and price elasticities, the results are presented in Tables 1 and 2. As we know, the elasticities of demand are non-linear functions of parameters of AIDS model and as such their standard errors are not directly available. To 
overcome this deficiency all the elasticities are re-estimated repeatedly using 250 samples with replacement following bootstrapping. This provides sufficient information to compute standard errors and, hence, t-statistics ${ }^{7}$.

We start with income elasticities presented in last column of the tables. The results show that in both the samples, the lowest value of income elasticity is for grains, followed by fuel and clothing, which are all less than one indicating that these goods are relative necessities. Other food category is also classified as relative necessity.

On the other extreme, income elasticity is the highest for transport and communications, following by housing and miscellaneous non-food items. The only difference in the nature of income elasticities is that the category of milk, meat and oil is classified as relative necessity in urban sample but relative luxury in the rural sample.

The overall impression that we draw from the pattern of income elasticities is that sensitivity of household demands to change in income is in accordance with common-sense expectations and no substantial differences in this respect exist between rural and urban households.

In contrast, when it comes to price elasticities, substantial differences in behavior between the two samples are observed. Although all the estimated own price elasticities are found to be negative and statistically significant both for the rural and urban areas, their relative magnitudes differ considerably between the two samples. In the urban sample own price elasticities are on lower side between -0.5 and -0.59 for three categories of goods namely grains; milk, meat and oil; and transport and communications. This is followed by the own price elasticity for clothing. Other foods and fuel have own price elasticities close to minus one. This leaves only two goods categories, housing and miscellaneous non-foods that have absolute values of the own price elasticity greater than one.

\footnotetext{
${ }^{7}$ Various experiments show that the standards errors become almost stable when the number of bootstrap experiments exceeds 200 .
} 
Table 1: Price and Income Elasticities Based on AIDS for Urban Pakistan

\begin{tabular}{|c|c|c|c|c|c|c|c|c|c|}
\hline $\begin{array}{l}\text { Commodity } \\
\text { group }\end{array}$ & Grains & $\begin{array}{c}\text { Milk, } \\
\text { Meat } \\
\text { and Oil }\end{array}$ & $\begin{array}{l}\text { Other } \\
\text { foods }\end{array}$ & Clothing & Housing & Fuel & $\begin{array}{c}\text { Transport, } \\
\text { etc. }\end{array}$ & $\begin{array}{l}\text { Other } \\
\text { Non- } \\
\text { Food }\end{array}$ & $\begin{array}{c}\text { Income } \\
\text { Elasticity }\end{array}$ \\
\hline Grains & $\begin{array}{c}-0.592 \\
(-33.28 *)\end{array}$ & $\begin{array}{c}0.217 \\
(11.52 *)\end{array}$ & $\begin{array}{c}0.457 \\
\left(6.74^{*}\right)\end{array}$ & $\begin{array}{c}-0.079 \\
(-4.31 *)\end{array}$ & $\begin{array}{l}-0.329 \\
(-9.19)\end{array}$ & $\begin{array}{c}0.016 \\
\left(9.19^{*}\right)\end{array}$ & $\begin{array}{c}-0.171 \\
(-3.70 *)\end{array}$ & $\begin{array}{l}-0.128 \\
\left(-4.20^{*}\right)\end{array}$ & $\begin{array}{c}0.626 \\
\left(171.0^{*}\right)\end{array}$ \\
\hline $\begin{array}{l}\text { Milk, Meat and } \\
\text { Oil }\end{array}$ & $\begin{array}{c}0.085 \\
(9.32 *)\end{array}$ & $\begin{array}{c}-0.502 \\
(-21.38 *)\end{array}$ & $\begin{array}{c}-0.147 \\
\left(-9.19^{*}\right)\end{array}$ & $\begin{array}{c}-0.020 \\
(-1.93 * * *)\end{array}$ & $\begin{array}{c}-0.237 \\
\left(-9.77^{*}\right)\end{array}$ & $\begin{array}{c}0.027 \\
\left(10.60^{*}\right)\end{array}$ & $\begin{array}{c}-0.101 \\
(-5.29 *)\end{array}$ & $\begin{array}{l}-0.020 \\
(-0.68)\end{array}$ & $\begin{array}{c}0.918 \\
\left(161.4^{*}\right)\end{array}$ \\
\hline Other Foods & $\begin{array}{c}0.286 \\
(6.58 *)\end{array}$ & $\begin{array}{l}-0.195 \\
\left(-8.99^{*}\right)\end{array}$ & $\begin{array}{c}-0.961 \\
(-16.91 *)\end{array}$ & $\begin{array}{l}-0.141 \\
\left(-6.63^{*}\right)\end{array}$ & $\begin{array}{c}0.142 \\
\left(2.86^{*}\right)\end{array}$ & $\begin{array}{c}-0.011 \\
(-4.52 *)\end{array}$ & $\begin{array}{c}-0.319 \\
\left(-7.94^{*}\right)\end{array}$ & $\begin{array}{c}0.262 \\
\left(3.55^{*}\right)\end{array}$ & $\begin{array}{c}0.939 \\
\left(274.0^{*}\right)\end{array}$ \\
\hline Clot & $\begin{array}{c}-0.152 \\
(-4.87 *)\end{array}$ & $\begin{array}{l}-0.054 \\
(-1.61)\end{array}$ & $\begin{array}{c}-0.346 \\
\left(-6.46^{*}\right)\end{array}$ & $\begin{array}{c}-0.765 \\
\left(-14.33^{*}\right)\end{array}$ & $\begin{array}{l}0.109 \\
(1.08)\end{array}$ & $\begin{array}{c}0.012 \\
\left(3.74^{*}\right)\end{array}$ & $\begin{array}{l}-0 \\
(-.\end{array}$ & $\begin{array}{c}0.350 \\
\left(9.08^{*}\right)\end{array}$ & $\begin{array}{c}0.894 \\
\left(260.4^{*}\right)\end{array}$ \\
\hline Housing & $\begin{array}{c}-0.246 \\
(-13.04 *)\end{array}$ & $\begin{array}{c}-0.308 \\
(-11.82 *)\end{array}$ & $\begin{array}{c}0.076 \\
\left(2.05^{* *}\right)\end{array}$ & $\begin{array}{l}0.021 \\
(0.63)\end{array}$ & $\begin{array}{c}-1.102 \\
(-23.52 *)\end{array}$ & $\begin{array}{c}0.011 \\
(5.03 *)\end{array}$ & $\begin{array}{c}0.304 \\
\left(12.70^{*}\right)\end{array}$ & $\begin{array}{l}0.021 \\
(0.39)\end{array}$ & $\begin{array}{c}1.212 \\
\left(142.6^{*}\right)\end{array}$ \\
\hline Fuel & $\begin{array}{l}-0.003 \\
(-1.12)\end{array}$ & $\begin{array}{c}0.074 \\
\left(18.19^{*}\right)\end{array}$ & $\begin{array}{c}-0.010 \\
\left(-2.26^{* *}\right)\end{array}$ & $\begin{array}{c}0.008 \\
\left(3.60^{*}\right)\end{array}$ & $\begin{array}{c}0.083 \\
\left(16.16^{*}\right)\end{array}$ & $\begin{array}{c}-1.037 \\
\left(-402.9^{*}\right)\end{array}$ & $\begin{array}{c}-0.009 \\
(-2.23 * *)\end{array}$ & $\begin{array}{c}0.022 \\
\left(2.30^{* *}\right)\end{array}$ & $\begin{array}{c}0.878 \\
\left(115.0^{*}\right)\end{array}$ \\
\hline $\begin{array}{l}\text { Transport and } \\
\text { Communication }\end{array}$ & $\begin{array}{c}-0.348 \\
(-5.01 *)\end{array}$ & $\begin{array}{l}-0.371 \\
\left(-674^{*}\right)\end{array}$ & $\begin{array}{c}-0.772 \\
\left(-8.21^{*}\right)\end{array}$ & $\begin{array}{l}-0.057 \\
(-0.78)\end{array}$ & $\begin{array}{c}0.854 \\
\left(12.98^{*}\right)\end{array}$ & $\begin{array}{c}-0.045 \\
(-8.42 *)\end{array}$ & $\begin{array}{c}-0.500 \\
\left(-5.66^{*}\right)\end{array}$ & $\begin{array}{l}-0.035 \\
(-0.39)\end{array}$ & $\begin{array}{c}1.262 \\
\left(115.6^{*}\right)\end{array}$ \\
\hline $\begin{array}{l}\text { Other Non- } \\
\text { Food }\end{array}$ & $\begin{array}{c}-0.130 \\
(-7.80 *)\end{array}$ & $\begin{array}{c}-0.065 \\
(-2.07 * *)\end{array}$ & $\begin{array}{c}0.183 \\
(2.99 *)\end{array}$ & $\begin{array}{c}0.100 \\
\left(7.84^{*}\right)\end{array}$ & $\begin{array}{l}0.044 \\
(0.76)\end{array}$ & $\begin{array}{c}-0.012 \\
(-3.34 *)\end{array}$ & $\begin{array}{l}-0.004 \\
(-0.11)\end{array}$ & $\begin{array}{c}-1.249 \\
\left(-34.90^{*}\right)\end{array}$ & $\begin{array}{c}1.127 \\
\left(257.5^{*}\right)\end{array}$ \\
\hline
\end{tabular}

Note: $\quad$ Each row of the table shows elasticities of the commodity group in the row. The t-values (in parentheses) show significance at $1 \%, 5 \%$ and $10 \%$ are indicated by $*, * *$ and $* * *$, respectively.

Table 2: Price and Income Elasticities Based on AIDS for Rural Pakistan

\begin{tabular}{|c|c|c|c|c|c|c|c|c|c|}
\hline $\begin{array}{l}\text { Commodity } \\
\text { group }\end{array}$ & Grains & $\begin{array}{c}\text { Milk, } \\
\text { Meat } \\
\text { and Oil }\end{array}$ & $\begin{array}{l}\text { Other } \\
\text { foods }\end{array}$ & Clothing & Housing & Fuel & $\begin{array}{l}\text { Transpo } \\
\text { rt, etc. }\end{array}$ & $\begin{array}{l}\text { Other } \\
\text { Non- } \\
\text { Food }\end{array}$ & $\begin{array}{c}\text { Income } \\
\text { Elasticity }\end{array}$ \\
\hline Grains & $\begin{array}{c}-0.931 \\
\left(-42.73^{*}\right)\end{array}$ & $\begin{array}{c}0.376 \\
(23.79 *)\end{array}$ & $\begin{array}{l}-0.016 \\
(-1.49)\end{array}$ & $\begin{array}{c}-0.228 \\
\left(-12.77^{*}\right)\end{array}$ & $\begin{array}{c}0.207 \\
\left(10.27^{*}\right)\end{array}$ & $\begin{array}{c}0.068 \\
\left(10.97^{*}\right)\end{array}$ & $\begin{array}{l}-0.010 \\
(-0.66)\end{array}$ & $\begin{array}{c}-0.214 \\
\left(-10.23^{*}\right)\end{array}$ & $\begin{array}{c}0.762 \\
(-248.7 *)\end{array}$ \\
\hline $\begin{array}{l}\text { Milk, Meat and } \\
\text { Oil }\end{array}$ & $\begin{array}{c}0.196 \\
\left(19.95^{*}\right)\end{array}$ & $\begin{array}{c}-1.015 \\
\left(-80.19^{*}\right)\end{array}$ & $\begin{array}{c}0.061 \\
\left(6.66^{*}\right)\end{array}$ & $\begin{array}{c}-0.046 \\
\left(-5.48^{*}\right)\end{array}$ & $\begin{array}{l}-0.093 \\
\left(-8.73^{*}\right)\end{array}$ & $\begin{array}{l}-0.005 \\
(-1.12)\end{array}$ & $\begin{array}{c}0.146 \\
\left(11.30^{*}\right)\end{array}$ & $\begin{array}{c}-0.264 \\
\left(-12.87^{*}\right)\end{array}$ & $\begin{array}{c}1.017 \\
(547.2 *)\end{array}$ \\
\hline Other Foods & $\begin{array}{c}-0.046 \\
(-4.58 *)\end{array}$ & $\begin{array}{c}0.109 \\
(7.91 *)\end{array}$ & $\begin{array}{c}-1.048 \\
\left(-77.10^{*}\right)\end{array}$ & $\begin{array}{c}-0.094 \\
\left(-9.77^{*}\right)\end{array}$ & $\begin{array}{c}-0.064 \\
\left(-4.71^{*}\right)\end{array}$ & $\begin{array}{c}0.011 \\
\left(2.30^{* *}\right)\end{array}$ & $\begin{array}{c}0.222 \\
\left(13.22^{*}\right)\end{array}$ & $\begin{array}{c}-0.048 \\
(-2.28 * *)\end{array}$ & $\begin{array}{c}0.960 \\
\left(454.2^{*}\right)\end{array}$ \\
\hline Clothing & $\begin{array}{c}-0.525 \\
\left(-13.20^{*}\right)\end{array}$ & $\begin{array}{c}-0.140 \\
\left(-4.85^{*}\right)\end{array}$ & $\begin{array}{c}-0.212 \\
\left(-9.42^{*}\right)\end{array}$ & $\begin{array}{c}-0.673 \\
(-12.97 *)\end{array}$ & $\begin{array}{l}0.043 \\
(0.87)\end{array}$ & $\begin{array}{c}-0.046 \\
(-6.98 *)\end{array}$ & $\begin{array}{c}0.101 \\
\left(3.16^{*}\right)\end{array}$ & $\begin{array}{c}0.512 \\
\left(15.47^{*}\right)\end{array}$ & $\begin{array}{c}0.945 \\
(451.2 *)\end{array}$ \\
\hline Housing & $\begin{array}{c}0.247 \\
(8.53 *)\end{array}$ & $\begin{array}{c}-0.269 \\
(-11.24 *)\end{array}$ & $\begin{array}{c}-0.133 \\
\left(-6.40^{*}\right)\end{array}$ & $\begin{array}{l}0.022 \\
(0.70)\end{array}$ & $\begin{array}{c}-1.221 \\
\left(-28.48^{*}\right)\end{array}$ & $\begin{array}{c}-0.042 \\
\left(-4.46^{*}\right)\end{array}$ & $\begin{array}{c}-0.298 \\
(-8.74 *)\end{array}$ & $\begin{array}{c}0.491 \\
\left(10.83^{*}\right)\end{array}$ & $\begin{array}{c}1.191 \\
\left(227.6^{*}\right)\end{array}$ \\
\hline Fuel & $\begin{array}{c}0.101 \\
\left(10.27^{*}\right)\end{array}$ & $\begin{array}{c}0.041 \\
(3.79 *)\end{array}$ & $\begin{array}{c}0.037 \\
(4.62 *)\end{array}$ & $\begin{array}{c}-0.033 \\
\left(-7.08^{*}\right)\end{array}$ & $\begin{array}{l}-0.013 \\
(-1.32)\end{array}$ & $\begin{array}{c}-1.022 \\
(-126.9 *)\end{array}$ & $\begin{array}{c}-0.060 \\
\left(-5.83^{*}\right)\end{array}$ & $\begin{array}{c}0.110 \\
\left(7.05^{*}\right)\end{array}$ & $\begin{array}{c}0.848 \\
\left(229.7^{*}\right)\end{array}$ \\
\hline $\begin{array}{l}\text { Transport and } \\
\text { Communication }\end{array}$ & $\begin{array}{c}-0.094 \\
(-2.38 * *)\end{array}$ & $\begin{array}{c}0.493 \\
(10.08 *)\end{array}$ & $\begin{array}{c}0.536 \\
\left(12.35^{*}\right)\end{array}$ & $\begin{array}{c}0.106 \\
(3.01 *)\end{array}$ & $\begin{array}{l}-0.515 \\
\left(-8.88^{*}\right)\end{array}$ & $\begin{array}{c}-0.128 \\
(-7.78 *)\end{array}$ & $\begin{array}{c}-1.440 \\
(-25.89 *)\end{array}$ & $\begin{array}{l}-0.206 \\
(-3.72 *)\end{array}$ & $\begin{array}{c}1.234 \\
\left(248.9^{*}\right)\end{array}$ \\
\hline $\begin{array}{l}\text { Other Non- } \\
\text { Food }\end{array}$ & $\begin{array}{c}-0.235 \\
\left(-13.35^{*}\right)\end{array}$ & $\begin{array}{c}-0.369 \\
\left(-13.90^{*}\right)\end{array}$ & $\begin{array}{c}-0.066 \\
(-3.68 *)\end{array}$ & $\begin{array}{c}0.180 \\
(14.64 *)\end{array}$ & $\begin{array}{c}0.279 \\
\left(10.71^{*}\right)\end{array}$ & $\begin{array}{c}0.033 \\
\left(4.13^{*}\right)\end{array}$ & $\begin{array}{c}-0.059 \\
\left(-3.22^{*}\right)\end{array}$ & $\begin{array}{c}-0.899 \\
(-28.30 *)\end{array}$ & $\begin{array}{c}1.129 \\
\left(422.3^{*}\right)\end{array}$ \\
\hline
\end{tabular}

Note: Each row of the table shows elasticities of the commodity group in the row. The t-values (in parentheses) show significance at $1 \%, 5 \%$ and $10 * \%$ are indicated by $*$, $* *$ and $* * *$, respectively. 
On the other hand, for the rural sample most of the own price elasticities are greater than or close to one, the lowest being for clothing (at -0.67) followed by miscellaneous non-food category (at -0.90). Surprisingly, even the own price elasticity for grains is not too low; it is 0.93. A possible explanation could be that since rural sector is a net supplier of grains to urban sector, increase in price has direct negative effect on demand for grains as consumer good as well as the indirect negative effect when higher price stimulates increase in supply to market. All the other five goods categories have absolute values of the own price elasticity greater than one, the highest being for transport and communications.

Cross price elasticities are found to differ considerately between the two samples not only in magnitudes but also in terms of signs. Of the 56 cross price elasticities about half (27) have opposite signs in the two samples. A notable difference in the cross price elasticities between the two samples can be seen for the categories of housing and transport and communications. While in rural sample, $3 / 7$ cross price elasticities of housing demand with respect to prices of other goods and 3/7 cross price elasticities of other goods' demands with respect to housing price are positive, in the urban sample the similar cross price elasticities involving housing demand or housing price are five. In other words, in rural areas housing forms a complementarity relationship with most of the other goods, but in urban areas it is considered a substitute with most of the other goods.

In rural areas housing and transport and communications have the strongest complementarity relationship. In contrast, in the urban areas housing and transport and communications form the strongest substitutability relationship. Since housing is by far more expensive in urban areas, especially in large cities; its demand seems quite responsive not only to income and housing price but also to price of other goods, especially transport and communications. Urban households often found to prefer living in cheaper homes in outskirts of cities at the cost of higher transportation expenditures. In case they have to live inside cities, they would prefer to locate near to their workplaces to minimize transportation expenses.

We close this discussion by commenting on the elasticities results from the perspective of commodity taxation. There are two important considerations of this study. The first is that the commodities on which poor 
households spend a larger percentage of their incomes, ${ }^{8}$ may be exempted from tax or subjected to low tax rates, while the goods on which rich households spend a larger percentage of their incomes may be subjected to higher tax rates. This boils down the rule that the goods with higher income elasticities may be taxed more heavily. The second consideration is the potential for tax collection keeping in view the magnitude of own price elasticity and the placement on the tax Laffer Curve. It can be readily shown that an increase in ad valorem tax rate $t$ will increase tax revenue if $(1+t) / t$ is greater than the absolute value of own price elasticity. If, for example, tax rate is as high as $20 \%$, a tax increase will still improve tax collection as long as the absolute value of own price elasticity is less than six. Since this condition is easily met according to our estimates of own price elasticities, The study focuses on the first consideration based on income elasticity. The results therefore indicate that transport and communications and miscellaneous non-food goods (especially durables other than furniture and fixtures, laundry, etc.) and housing have relatively high-income elasticities and can be taxed more heavily. ${ }^{9}$

\section{Concluding Remarks}

The empirical work on household demand for Pakistan is severely constrained by limited data availability. The literature mostly relies on cross-section data that do not permit estimation of full demand system, while the few studies on complete demand system using genuine price variation over time have employed grouped rather than micro data, resulting in a substantial loss of information.

This study analyzes household demand behavior using pooled data of nine micro-level cross-sectional data sets and making use of the information contained both in cross-sectional as well as time dimensions. The study makes use of year-to-year as well as month-to-month price variation in pooled data. The analysis is based on income and prices elasticity estimates derived from Almost Ideal demand System (AIDS) and their standard errors estimates are obtained using Bootstrap simulations. Consumer goods are classified into eight broad categories: Clothing;

\footnotetext{
${ }^{8}$ If income elasticity for a good is less than one, the expenditure share of that good increases with the decrease in income. Comparing any two goods, the expenditure on the one having lower income elasticity relative to the expenditure on the other good will increase in response to decrease in income.

${ }^{9}$ These are the broad lessens that follow from the present analysis. Actual taxation policies might include other socioeconomic and political considerations as well.
} 
Housing; Grains; Milk, Meat and Oil; Other Foods; Fuel; Transport and Communication; and all other non-food goods (miscellaneous).

The study finds that sensitivity of household demands to change in income is in accordance with common-sense expectations and no substantial differences in this respect exist between rural and urban households. On the other hand, substantial differences are observed in demand responses to changes in prices. Although all own price elasticities are negative and statistically significant both for the rural and urban areas, their relative magnitudes are quite different between the two samples. On average rural households are found to be more responsive to price changes than the urban households.

Cross price elasticities are also different between the two samples not only in terms of magnitudes but also in terms of signs. A notable observation is that in rural areas housing and transport and communications have the strongest complementarity relationship. In contrast, in the urban areas housing and transport and communications form the strongest substitutability relationship. Since housing is more expensive in urban areas, especially in large cities; its demand seems quite responsive not only to income and housing price but also to price of other goods, especially transport and communications. Urban household often found to prefer living in cheaper homes in outskirts of cities at the cost of higher transportation expenditures. In case they have to live inside cities, they would prefer to locate near to their workplaces to minimize transportation expenses.

On equity considerations, the study concludes that transport and communications and miscellaneous non-food goods (especially durables other than furniture and fixtures, laundry, etc.) and housing can be taxed more heavily because all these goods have income elasticities on higher side. 


\section{References}

Ahmad, E., Abrar, M. A. I., \& Saghir, G. (2020). Welfare analysis of energy pricing in Pakistan. Pakistan Economic and Social Review, 58(1), 134.

Ahmad, E., \& Arshad, M. (2007). Household budget analysis for Pakistan under varying the parameter approach. Pakistan Institute of Development Economics, Working Paper, 2007: 41.

Ahmad, E., Jalil, A., \& Idrees, M. (2013). Almost ideal demand system and uniform taxation in Pakistan: Econometric evidence for consumer goods in Pakistan 1984-2008. Applied Econometrics and International Development, 13(2), 211-220.

Ahmad, E., \& Ludlow, S (1987). Aggregate and regional demand response in Pakistan. The Pakistan Development Review, 26(4), 645-655.

Ahmad, E., Ludlow, S., \& Stern, N. (1988). Demand response in Pakistan: A modification of linear expenditure system for 1976. The Pakistan Development Review, 27(3), 293-308.

Ahmad, E., \& Malik, N. (1989). Rural-urban and provincial differences in household expenditure pattern in Pakistan. Pakistan Journal of Applied Economics, 8(2), 117-134.

Ali, M. S. (1981). Rural urban consumption pattern in Pakistan. Pakistan Economic and Social Review, 19(2), 85-94.

Ali, M. S. (1985). Household consumption and saving behavior in Pakistan: An application of the extended linear expenditure system. The Pakistan Development Review, 24(1), 23-38.

Aziz, B., \& Malik, S. (2010). Household consumption patterns in Pakistan: A rural-urban analysis. Forman Journal of Economic Studies, 6, 125.

Burki, A. A. (1997). Estimating consumer preferences for food, using time series data of Pakistan. The Pakistan Development Review, 36(2), 131-153.

Burney, N. A., \& Akhtar, N. (1990). Fuel demand elasticities in Pakistan: An analysis of households' expenditure on fuels using micro data. The Pakistan Development Review, 29(2), 155-174. 
Burney, N., \& Khan, A. H. (1991). Households consumption pattern in Pakistan: An urban-rural comparison using micro data. The Pakistan Development Review, 30(1), 145-171.

Deaton, A., \& Muellbauer, J. (1980). An almost ideal demand system. The American Economic Review, 70(3), 312-326.

Ekholm, T., Krey, V., Pachauri, S., \& Riahi, K. (2010). Determinants of household energy consumption in India. Energy Policy, 38(10), 5696-5707.

Green, R., \& Alston, J. M. (1990). Elasticities in AIDS models. American Journal of Agricultural Economics, 72(2), 442-445.

Green, R., \& Alston, J. M. (1991). Elasticities in AIDS models: A clarification and extension. American Journal of Agricultural Economics, 73(3), 874-875.

Alston, J. M., \& Chalfant, J. A. (1993). The silence of the lambdas: A test of the almost ideal and Rotterdam models. American Journal of Agricultural Economics, 75(2), 304-313.

Hay, F.G., \& Sinha, R.P. (1972). Analysis of food expenditure patterns of industrial workers and their families in a developing country. The Journal of Development Studies, 8(4), 425-446.

Jamil, F., \& Ahmad, E. (2010). The relationship between electricity consumption, electricity prices and GDP in Pakistan. Energy Policy, 38, 6016-6025.

Jamil, F., \& Ahmad, E. (2011). Income and price elasticities of electricity demand: Aggregate and sector-wise analyses. Energy Policy, 39, 5519-5527.

Khan, M. A., \& Ahmed, U. (2009). Energy demand in Pakistan: A disaggregate analysis. The Pakistan Development Review, 47(4), 437-455.

Malik, S., Abbas, K., \& Ghani, E. (1987). Rural urban differences and the stability of consumption behavior: An intertemporal analysis of the household income and survey data for the period 1963-64 to 198485. The Pakistan Development Review, 26(4), 673-682.

Malik, S., Mushtaq, M., \& Ghani, E. (1988). Consumption pattern of major food items in Pakistan, provincial, sectoral and intertemporal 
differences 1979 to 1984-85. The Pakistan Development Review, 27(4), 751-759.

Massell, B. F. (1969). Consistent estimation of expenditure elasticities from cross-section data on households producing partly for subsistence. The Review of Economics and Statistics, 51(2), 136-142.

Ozer, H. (2003). Demand elasticities in Turkey. Journal of Economic Integration, 18(4), 837-852.

Ray, R. (1982). The testing and estimation of complete demand systems on household budget surveys: An application of AIDS. European Economic Review, 17(3), 349-369.

Shamim, F., \& Ahmad, E. (2007). Understanding household consumption pattern in Pakistan. Journal of Retailing and Consumer Services, 14, 150-164.

Yen, S. T., \& Jensen, H. H. (1996). Determinants of household expenditures on alcohol. Journal of Consumer Affairs, 30(1), 48-67. 


\section{Appendix}

Table A1: Parameter Estimates of AIDS for Urban Pakistan

\begin{tabular}{|c|c|c|c|c|c|c|c|c|c|c|c|c|c|c|c|c|}
\hline $\begin{array}{l}\text { Commodity } \\
\text { Group }\end{array}$ & $\boldsymbol{\alpha}_{i}$ & $\boldsymbol{\beta}_{i}$ & $\gamma_{i 1}$ & $\gamma_{i 2}$ & $\gamma_{i 3}$ & $\gamma_{i 4}$ & $\gamma_{i 5}$ & $\gamma_{i 6}$ & $\gamma_{i 7}$ & $\gamma_{i 8}$ & $\underset{\mathbf{A}}{\mathbf{I N F} \mathbf{Y}_{-}}$ & $\mathbf{I N F}_{\mathbf{U}} \mathbf{Y}_{-}$ & LY_A & LY_U & G_Y & $\mathbf{R}^{2}$ \\
\hline Grains & $\begin{array}{c}1.361 \\
(22.53 *)\end{array}$ & $\begin{array}{c}-0.038 \\
\left(-125.6^{*}\right)\end{array}$ & $\begin{array}{c}0.036 \\
\left(12.68^{*}\right)\end{array}$ & $\begin{array}{c}0.014 \\
(6.29 *)\end{array}$ & $\begin{array}{c}0.041 \\
\left(16.33^{*}\right)\end{array}$ & $\begin{array}{l}-0.010 \\
(-3.62 *)\end{array}$ & $\begin{array}{c}-0.039 \\
\left(-16.39^{*}\right)\end{array}$ & $\begin{array}{c}-0.001 \\
\left(-4.81^{*}\right)\end{array}$ & $\begin{array}{c}-0.020 \\
\left(-7.85^{*}\right)\end{array}$ & $\begin{array}{c}-0.021 \\
\left(-4.79^{*}\right)\end{array}$ & $\begin{array}{c}0.001 \\
\left(2.74^{*}\right)\end{array}$ & $\begin{array}{c}-0.003 \\
\left(-9.11^{*}\right)\end{array}$ & $\begin{array}{c}-0.085 \\
(-19.12 *)\end{array}$ & $\begin{array}{c}0.197 \\
\left(12.71^{*}\right)\end{array}$ & $\begin{array}{c}-0.189 \\
\left(-11.55^{*}\right)\end{array}$ & 0.43 \\
\hline $\begin{array}{l}\text { Milk, Meat and } \\
\text { Oil }\end{array}$ & $\begin{array}{c}1.462 \\
\left(22.44^{*}\right)\end{array}$ & $\begin{array}{c}-0.015 \\
(-51.47 *)\end{array}$ & $\begin{array}{c}0.014 \\
(6.29 *)\end{array}$ & $\begin{array}{c}0.091 \\
\left(25.78^{*}\right)\end{array}$ & $\begin{array}{c}-0.030 \\
(-10.67 *)\end{array}$ & $\begin{array}{l}-0.004 \\
(1.57)\end{array}$ & $\begin{array}{c}-0.047 \\
(-16.99 *)\end{array}$ & $\begin{array}{c}0.004 \\
(12.47 *)\end{array}$ & $\begin{array}{c}-0.020 \\
(-6.91 *)\end{array}$ & $\begin{array}{l}-0.007 \\
(-1.52)\end{array}$ & $\begin{array}{c}-0.001 \\
(-3.04 *)\end{array}$ & $\begin{array}{l}-0.001 \\
(-0.83)\end{array}$ & $\begin{array}{c}-0.089 \\
(-18.71 *)\end{array}$ & $\begin{array}{c}0.197 \\
\left(12.65^{*}\right)\end{array}$ & $\begin{array}{c}0.074 \\
\left(4.45^{*}\right)\end{array}$ & 0.07 \\
\hline Other foods & $\begin{array}{c}0.503 \\
\left(7.38^{*}\right)\end{array}$ & $\begin{array}{c}-0.009 \\
(-29.58 *)\end{array}$ & $\begin{array}{c}0.041 \\
\left(16.33^{*}\right)\end{array}$ & $\begin{array}{c}-0.030 \\
(-10.67 *)\end{array}$ & $\begin{array}{c}0.004 \\
(0.090)\end{array}$ & $\begin{array}{c}-0.021 \\
(-5.89 *)\end{array}$ & $\begin{array}{c}0.019 \\
(5.72 *)\end{array}$ & $\begin{array}{c}-0.002 \\
\left(-7.11^{*}\right)\end{array}$ & $\begin{array}{c}-0.047 \\
\left(-13.13^{*}\right)\end{array}$ & $\begin{array}{c}0.037 \\
(7.62 *)\end{array}$ & $\begin{array}{c}0.004 \\
\left(11.33^{*}\right)\end{array}$ & $\begin{array}{c}0.005 \\
\left(14.26^{*}\right)\end{array}$ & $\begin{array}{c}-0.028 \\
\left(-5.65^{*}\right)\end{array}$ & $\begin{array}{c}-0.231 \\
(-14.52 *)\end{array}$ & $\begin{array}{c}0.232 \\
\left(13.49^{*}\right)\end{array}$ & 0.05 \\
\hline Clothing & $\begin{array}{c}-0.534 \\
\left(-8.25^{*}\right)\end{array}$ & $\begin{array}{c}-0.006 \\
\left(-20.35^{*}\right)\end{array}$ & $\begin{array}{l}-0.010 \\
(-3.62 *)\end{array}$ & $\begin{array}{l}-0.004 \\
(1.57)\end{array}$ & $\begin{array}{c}-0.021 \\
(-5.89 *)\end{array}$ & $\begin{array}{c}0.013 \\
(2.81 *)\end{array}$ & $\begin{array}{l}0.005 \\
(1.59)\end{array}$ & $\begin{array}{l}0.000 \\
(0.65)\end{array}$ & $\begin{array}{l}-0.003 \\
(-0.84)\end{array}$ & $\begin{array}{c}0.019 \\
(4.02 *)\end{array}$ & $\begin{array}{l}-0.002 \\
\left(-3.8^{*}\right)\end{array}$ & $\begin{array}{l}0.001 \\
(1.18)\end{array}$ & $\begin{array}{c}0.046 \\
(9.69 *)\end{array}$ & $\begin{array}{c}-0.054 \\
\left(-3.41^{*}\right)\end{array}$ & $\begin{array}{l}0.02 \\
(1.39)\end{array}$ & 0.07 \\
\hline Housing & $\begin{array}{c}-0.939 \\
\left(-14.75^{*}\right)\end{array}$ & $\begin{array}{c}0.038 \\
\left(126.6^{*}\right)\end{array}$ & $\begin{array}{c}-0.039 \\
(-16.27 *)\end{array}$ & $\begin{array}{c}-0.047 \\
(-16.99 *)\end{array}$ & $\begin{array}{c}0.019 \\
(5.72 *)\end{array}$ & $\begin{array}{l}0.005 \\
(1.59)\end{array}$ & $\begin{array}{c}-0.013 \\
\left(-2.90^{*}\right)\end{array}$ & $\begin{array}{c}0.005 \\
\left(15.66^{*}\right)\end{array}$ & $\begin{array}{c}0.058 \\
\left(16.97^{*}\right)\end{array}$ & $\begin{array}{c}0.011 \\
(2.47 *)\end{array}$ & $\begin{array}{c}-0.002 \\
(-6.52 *)\end{array}$ & $\begin{array}{c}0.004 \\
\left(10.5^{*}\right)\end{array}$ & $\begin{array}{c}0.076 \\
(16.54 *)\end{array}$ & $\begin{array}{c}-0.39 \\
\left(-24.36^{*}\right)\end{array}$ & $\begin{array}{c}0.16 \\
(9.64 *)\end{array}$ & 0.15 \\
\hline Fuel & $\begin{array}{c}0.917 \\
(20.81 *)\end{array}$ & $\begin{array}{c}-0.010 \\
(-32.47 *)\end{array}$ & $\begin{array}{l}-0.001 \\
(-4.81 *)\end{array}$ & $\begin{array}{c}0.004 \\
\left(12.47^{*}\right)\end{array}$ & $\begin{array}{c}-0.002 \\
(-7.11 *)\end{array}$ & $\begin{array}{l}0.000 \\
(0.65)\end{array}$ & $\begin{array}{c}0.005 \\
\left(15.66^{*}\right)\end{array}$ & $\begin{array}{c}-0.004 \\
\left(-12.70^{*}\right)\end{array}$ & $\begin{array}{c}-0.002 \\
(-4.64 *)\end{array}$ & $\begin{array}{c}0.001 \\
(-0.26)\end{array}$ & $\begin{array}{c}0.003 \\
\left(13.78^{*}\right)\end{array}$ & $\begin{array}{c}-0.002 \\
\left(-8.87^{*}\right)\end{array}$ & $\begin{array}{c}-0.06 \\
\left(-18.71^{*}\right)\end{array}$ & $\begin{array}{c}0.197 \\
\left(12.96^{*}\right)\end{array}$ & $\begin{array}{c}-0.161 \\
\left(-10.34^{*}\right)\end{array}$ & 0.08 \\
\hline $\begin{array}{l}\text { Transport and } \\
\text { Communication }\end{array}$ & $\begin{array}{c}-1.199 \\
(-17.03 *)\end{array}$ & $\begin{array}{c}0.017 \\
\left(55.99^{*}\right)\end{array}$ & $\begin{array}{c}-0.020 \\
\left(-7.85^{*}\right)\end{array}$ & $\begin{array}{c}-0.020 \\
(-6.91 *)\end{array}$ & $\begin{array}{c}-0.047 \\
\left(-13.13^{*}\right)\end{array}$ & $\begin{array}{l}-0.003 \\
(-0.84)\end{array}$ & $\begin{array}{c}0.058 \\
\left(16.97^{*}\right)\end{array}$ & $\begin{array}{c}-0.002 \\
\left(4.64^{*}\right)\end{array}$ & $\begin{array}{c}0.034 \\
\left(6.43^{*}\right)\end{array}$ & $\begin{array}{l}0.001 \\
(0.21)\end{array}$ & $\begin{array}{c}0.003 \\
\left(8.35^{*}\right)\end{array}$ & $\begin{array}{c}0.002 \\
\left(5.36^{*}\right)\end{array}$ & $\begin{array}{c}0.085 \\
\left(16.85^{*}\right)\end{array}$ & $\begin{array}{c}-0.011 \\
(-0.7)\end{array}$ & $\begin{array}{l}-0.057 \\
\left(-3.4^{*}\right)\end{array}$ & 0.07 \\
\hline Other Non-Food & $\begin{array}{c}-1.570 \\
(-10.97 *)\end{array}$ & $\begin{array}{c}0.023 \\
\left(28.87^{*}\right)\end{array}$ & $\begin{array}{c}-0.021 \\
\left(-4.79^{*}\right)\end{array}$ & $\begin{array}{l}-0.007 \\
(-1.52)\end{array}$ & $\begin{array}{c}0.037 \\
(7.62 *)\end{array}$ & $\begin{array}{l}-0.019 \\
(4.02 *)\end{array}$ & $\begin{array}{c}0.011 \\
\left(2.47^{*}\right)\end{array}$ & $\begin{array}{c}0.001 \\
(-0.26)\end{array}$ & $\begin{array}{l}0.001 \\
(0.21)\end{array}$ & $\begin{array}{c}-0.040 \\
(-3.32 *)\end{array}$ & $\begin{array}{c}-0.006 \\
\left(-8.74^{*}\right)\end{array}$ & $\begin{array}{c}-0.006 \\
\left(-8.17^{*}\right)\end{array}$ & $\begin{array}{c}0.054 \\
\left(5.11^{*}\right)\end{array}$ & $\begin{array}{c}0.094 \\
\left(2.33^{*}\right)\end{array}$ & $\begin{array}{l}-0.081 \\
(-1.92)\end{array}$ & 0.14 \\
\hline
\end{tabular}

Note: The figures in parentheses represent t-values and * indicates that the parameter is significance at $5 \%$ level. 
Sher and Ahmad

Table A2: Parameter Estimates of AIDS for Rural Pakistan

\begin{tabular}{|c|c|c|c|c|c|c|c|c|c|c|c|c|c|c|c|c|}
\hline $\begin{array}{l}\text { Commodity } \\
\text { Group }\end{array}$ & $\boldsymbol{\alpha}_{i}$ & $\boldsymbol{\beta}_{i}$ & $\gamma_{i 1}$ & $\gamma_{i 2}$ & $\gamma_{i 3}$ & $\gamma_{i 4}$ & $\gamma_{i 5}$ & $\gamma_{i 6}$ & $\gamma_{i 7}$ & $\gamma_{i 8}$ & INF_Y_A & INF_Y_U & LY_A & LY_U & G_Y & $\mathbf{R}^{2}$ \\
\hline Grains & $\begin{array}{l}0.503 \\
\left(9.75^{*}\right)\end{array}$ & $\begin{array}{c}-0.035 \\
(-122.2 *)\end{array}$ & $\begin{array}{l}0.004 \\
(1.18)\end{array}$ & $\begin{array}{c}0.044 \\
(23.43 *)\end{array}$ & $\begin{array}{c}-0.008 \\
(-5.17 *)\end{array}$ & $\begin{array}{c}-0.034 \\
(-13.17 *)\end{array}$ & $\begin{array}{c}0.028 \\
(11.60 *)\end{array}$ & $\begin{array}{c}0.007 \\
(8.78 *)\end{array}$ & $\begin{array}{l}-0.003 \\
(-1.34)\end{array}$ & $\begin{array}{c}-0.037 \\
(-10.79 *)\end{array}$ & $\begin{array}{c}-0.004 \\
(-18.85 *)\end{array}$ & $\begin{array}{c}0.002 \\
(6.78 *)\end{array}$ & $\begin{array}{c}-0.021 \\
(-5.53 *)\end{array}$ & $\begin{array}{c}-0.219 \\
(-18.34 *)\end{array}$ & $\begin{array}{c}0.136 \\
\left(10.76^{*}\right)\end{array}$ & 0.26 \\
\hline $\begin{array}{l}\text { Milk, Meat and } \\
\text { Oil }\end{array}$ & $\begin{array}{l}-0.058 \\
(-1.24)\end{array}$ & $\begin{array}{c}0.004 \\
\left(13.50^{*}\right)\end{array}$ & $\begin{array}{c}0.044 \\
\left(23.43^{*}\right)\end{array}$ & $\begin{array}{l}-0.002 \\
(-0.91)\end{array}$ & $\begin{array}{c}0.014 \\
\left(9.85^{*}\right)\end{array}$ & $\begin{array}{l}-0.010 \\
\left(-4.95^{*}\right)\end{array}$ & $\begin{array}{c}-0.020 \\
(- \\
10.52 *)\end{array}$ & $\begin{array}{l}-0.001 \\
(-1.06)\end{array}$ & $\begin{array}{c}0.032 \\
(17.68 *)\end{array}$ & $\begin{array}{c}-0.057 \\
\left(-18.56^{*}\right)\end{array}$ & $\begin{array}{c}-0.003 \\
(-15.96 *)\end{array}$ & $\begin{array}{c}0.002 \\
(6.37 *)\end{array}$ & $\begin{array}{c}0.014 \\
(4.12 *)\end{array}$ & $\begin{array}{c}-0.224 \\
(-18.79 *)\end{array}$ & $\begin{array}{c}0.283 \\
(22.84 *)\end{array}$ & 0.02 \\
\hline Other foods & $\begin{array}{l}-0.071 \\
(-1.58)\end{array}$ & $\begin{array}{c}-0.006 \\
(-20.58 *)\end{array}$ & $\begin{array}{l}-0.008 \\
\left(-5.17^{*}\right)\end{array}$ & $\begin{array}{c}0.014 \\
\left(9.85^{*}\right)\end{array}$ & $\begin{array}{c}-0.008 \\
\left(-4.75^{*}\right)\end{array}$ & $\begin{array}{c}-0.014 \\
\left(-8.23^{*}\right)\end{array}$ & $\begin{array}{c}-0.010 \\
\left(-5.79^{*}\right)\end{array}$ & $\begin{array}{l}0.001 \\
(1.60)\end{array}$ & $\begin{array}{c}0.033 \\
(21.52 *)\end{array}$ & $\begin{array}{c}-0.008 \\
(-2.66 *)\end{array}$ & $\begin{array}{c}0.002 \\
\left(10.64^{*}\right)\end{array}$ & $\begin{array}{c}0.004 \\
(17.22 *)\end{array}$ & $\begin{array}{l}0.014 \\
\left(4.1^{*}\right)\end{array}$ & $\begin{array}{c}-0.244 \\
\left(-20.51^{*}\right)\end{array}$ & $\begin{array}{c}0.221 \\
(17.84 *)\end{array}$ & 0.05 \\
\hline Clothing & $\begin{array}{c}-0.64 \\
(-12.51 *)\end{array}$ & $\begin{array}{c}-0.004 \\
(-12.31 *)\end{array}$ & $\begin{array}{c}-0.034 \\
(13.17 *)\end{array}$ & $\begin{array}{l}-0.010 \\
\left(-4.95^{*}\right)\end{array}$ & $\begin{array}{c}-0.014 \\
\left(-8.23^{*}\right)\end{array}$ & $\begin{array}{c}0.021 \\
\left(4.43^{*}\right)\end{array}$ & $\begin{array}{l}0.002 \\
(0.65)\end{array}$ & $\begin{array}{l}-0.003 \\
(-4.22 *)\end{array}$ & $\begin{array}{c}0.006 \\
\left(2.51^{*}\right)\end{array}$ & $\begin{array}{c}0.032 \\
\left(8.97^{*}\right)\end{array}$ & $\begin{array}{l}-0.001 \\
(-1.76)\end{array}$ & $\begin{array}{l}0.001 \\
(1.28)\end{array}$ & $\begin{array}{c}0.055 \\
\left(14.7^{*}\right)\end{array}$ & $\begin{array}{c}-0.066 \\
(-5.48 *)\end{array}$ & $\begin{array}{c}-0.035 \\
\left(-2.76^{*}\right)\end{array}$ & 0.05 \\
\hline Housing & $\begin{array}{c}1.689 \\
\left(32.75^{*}\right)\end{array}$ & $\begin{array}{c}0.019 \\
\left(65.09^{*}\right)\end{array}$ & $\begin{array}{c}0.028 \\
\left(11.60^{*}\right)\end{array}$ & $\begin{array}{c}-0.020 \\
(10.52 *)\end{array}$ & $\begin{array}{c}-0.010 \\
\left(-5.79^{*}\right)\end{array}$ & $\begin{array}{l}0.002 \\
(0.65)\end{array}$ & $\begin{array}{l}-0.020 \\
\left(-4.96^{*}\right)\end{array}$ & $\begin{array}{c}-0.002 \\
(-3.05 *)\end{array}$ & $\begin{array}{c}-0.028 \\
\left(-11.79^{*}\right)\end{array}$ & $\begin{array}{c}0.051 \\
\left(14.48^{*}\right)\end{array}$ & $\begin{array}{c}0.006 \\
\left(29.58^{*}\right)\end{array}$ & $\begin{array}{c}-0.002 \\
\left(-5.83^{*}\right)\end{array}$ & $\begin{array}{c}-0.117 \\
\left(-31.33^{*}\right)\end{array}$ & $\begin{array}{c}0.478 \\
(39.67 *)\end{array}$ & $\begin{array}{c}-0.488 \\
(- \\
\left.39.13^{*}\right)\end{array}$ & 0.08 \\
\hline Fuel & $\begin{array}{l}0.126 \\
(3.50 *)\end{array}$ & $\begin{array}{c}-0.014 \\
\left(-49.71^{*}\right)\end{array}$ & $\begin{array}{c}0.007 \\
\left(8.78^{*}\right)\end{array}$ & $\begin{array}{l}-0.001 \\
(-1.06)\end{array}$ & $\begin{array}{l}0.001 \\
(1.60)\end{array}$ & $\begin{array}{c}-0.003 \\
(-4.22 *)\end{array}$ & $\begin{array}{c}-0.002 \\
\left(-3.05^{*}\right)\end{array}$ & $\begin{array}{l}-0.003 \\
(4.25 *)\end{array}$ & $\begin{array}{c}-0.006 \\
(-7.94 *)\end{array}$ & $\begin{array}{l}0.008 \\
(4.27 *)\end{array}$ & $\begin{array}{c}0.002 \\
(6.81 *)\end{array}$ & $\begin{array}{c}0.002 \\
(8.77 *)\end{array}$ & $\begin{array}{l}-0.001 \\
(-0.28)\end{array}$ & $\begin{array}{c}-0.075 \\
(-6.31 *)\end{array}$ & $\begin{array}{c}0.128 \\
\left(10.46^{*}\right)\end{array}$ & 0.05 \\
\hline $\begin{array}{l}\text { Transport and } \\
\text { Communication }\end{array}$ & $\begin{array}{c}0.593 \\
\left(11.86^{*}\right)\end{array}$ & $\begin{array}{c}0.013 \\
(46.72 *)\end{array}$ & $\begin{array}{l}-0.003 \\
(-1.34)\end{array}$ & $\begin{array}{c}0.032 \\
(17.68 *)\end{array}$ & $\begin{array}{c}0.033 \\
(21.52 *)\end{array}$ & $\begin{array}{c}0.006 \\
\left(2.51^{*}\right)\end{array}$ & $\begin{array}{c}-0.028 \\
(- \\
11.79 *)\end{array}$ & $\begin{array}{c}-0.006 \\
(-7.94 *)\end{array}$ & $\begin{array}{c}-0.025 \\
\left(-8.56^{*}\right)\end{array}$ & $\begin{array}{c}0.010 \\
(-2.74 *)\end{array}$ & $\begin{array}{c}0.001 \\
\left(4.23^{*}\right)\end{array}$ & $\begin{array}{c}-0.003 \\
\left(-13.28^{*}\right)\end{array}$ & $\begin{array}{c}-0.039 \\
\left(-10.73^{*}\right)\end{array}$ & $\begin{array}{c}0.191 \\
\left(15.98^{*}\right)\end{array}$ & $\begin{array}{c}-0.079 \\
(-6.28 *)\end{array}$ & 0.05 \\
\hline Other Non-Food & $\begin{array}{c}-2.137 \\
\left(-19.56^{*}\right)\end{array}$ & $\begin{array}{c}0.023 \\
(-30.09 *)\end{array}$ & $\begin{array}{c}-0.037 \\
(-10.79 *)\end{array}$ & $\begin{array}{c}-0.057 \\
(- \\
\left.18.56^{*}\right)\end{array}$ & $\begin{array}{c}-0.008 \\
\left(-2.66^{*}\right)\end{array}$ & $\begin{array}{c}0.032 \\
(8.97 *)\end{array}$ & $\begin{array}{c}0.051 \\
(14.48 *)\end{array}$ & $\begin{array}{c}0.008 \\
(4.27 *)\end{array}$ & $\begin{array}{c}-0.010 \\
(-2.74 *)\end{array}$ & $\begin{array}{c}0.021 \\
(2.27 *)\end{array}$ & $\begin{array}{l}-0.003 \\
(-5.67 *)\end{array}$ & $\begin{array}{c}-0.004 \\
\left(-8.17^{*}\right)\end{array}$ & $\begin{array}{c}0.095 \\
\left(11.84^{*}\right)\end{array}$ & $\begin{array}{l}0.158 \\
\left(5.05^{*}\right)\end{array}$ & $\begin{array}{c}-0.166 \\
(-5.08 *)\end{array}$ & 0.05 \\
\hline
\end{tabular}

Note: The figures in parentheses represent $\mathrm{t}$-values and $*$ indicates that the parameter is significance at $5 \%$ level. 